\title{
PERGESERAN STRUKTUR EKONOMI DAN POTENSI SEKTOR EKONOMI KABUPATEN MANGGARAI PERIODE 2010-2015
}

\author{
Vol. 6, No 3. Maret 2017 \\ Eduardo Edwin Ramda \\ Made Suyana Utama
}

Untuk memenuhi matakuliah Geografi Ekonomi

Dosen pengampu: Roni Alim B.K, M. Pd

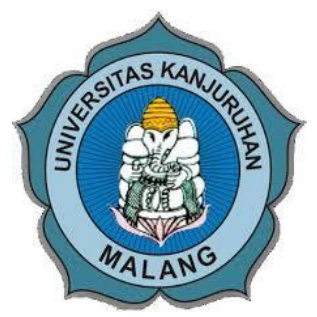

Oleh

Kelompok 14:

Fabiana Dai $\quad$ (160401050041)

Febriana Surmiarti Pae (160401050049)

UNIVERSITAS KANJURUHAN MALANG

FAKULTAS ILMU PENDIDIKAN

PROGRAM STUDI PENDIDIKAN GEOGRAFI 


\section{BAB I}

\section{PENDAHULUAN}

\subsection{Latar Belakang}

Kabupaten Manggarai merupakan daerah dengan potensi ekonomi yang beragam, namun mulai mengalami pergeseran struktur ekonomi. Pembangunan ekonomi regional merupakan implementasi dari perencanaan pembangunan nasional di suatu daerah yang disesuaikan dengan kemampuan sumber daya manusia (SDM), sosial, tingkat ekonomi dan regulasi yang berlaku (Purnomo\&Istiqomah 2008). Laju pertumbuhan ekonomi yang meningkat dan pergeseran struktur ekonomi merupakan tujuan dari adanya pembangunan ekonomi regional. Pergeseran struktur yang terjadi dapat berupa pergeseran dari sektor pertanian ke nonpertanian, sektor industry ke sektor jasa, perubahan dalam unit-unit produktif, serta perubahan status kerja buruh.

Pembangunan daerah merupakan komponen yang tidak dapat dipisahkan dari pembangunan nasional. Pembangunan daerah dapat dijalankan pada berbagai jenis aspek kehidupan melalui pelaksanaan pembangunan di bidang ekonomi. Apabila pembangunan di setiap daerah dapat terlaksana dengan baik, maka secara simultan tujuan pembangunan nasional akan tercapai. Oleh karena itu, secara langsung pembangunan daerah merupakan kunci dari keberhasilan pembangunan suatu negara.

Kabupaten Manggarai terdiri dari dua belas kecamatan dengan potensi daerahnya yang berbeda di setiap kecamatan. Keberadaan sektor perekonomian yang tersebar di Kabupaten Manggarai menghasilkan output ekonomi pada tujuh belas sektor ekonomi dan memberikan kontribusi bagi perekonomian di Kabupaten Manggarai. Kontribusi dari setiap sektor yang berbeda mengindikasikan bahwa Kabupaten Manggarai memiliki banyak potensi yang bisa dimanfaatkan sebagai penggerak roda perekonomian di Kabupaten Manggarai.

\subsection{Rumusan Masalah}

1. Apa yang di maksud dengan pergeseran struktur ekonomi?

2. Jelaskan 6 metode analisis dalam penelitian?

3. Sebutkan 6 sektor dalam menunjang perekonomian nasional? 


\subsection{Tujuan Penulisan}

1. Untuk mengetahui pengertian pergeseran struktur ekonomi.

2. Untuk mengetahui 6 metode analisis dalam penelitian.

3. Untuk mengetahui 6 sektor dalam menunjang perekonomian nasional. 


\section{BAB II}

\section{PEMBAHASAN}

2.1 Pengertian pergeseran struktur ekonomi

Pergeseran struktur ekonomi yang terjadi merupakan dampak yang terjadi akibat proses pertumbuhan ekonomi. Wiwekananda (2016) menyebutkan bahwa tingkat perubahan structural dan sektoral yang tinggi, berkaitan dengan proses pertumbuhan ekonomi. Sektor ekonomi tidak hanya berpengruh terhadap Produk Domestik Bruto (PDB) atau Produk Domestik Regional Bruto (PDRB) dan tingkat penyerapan kerja, tetapi juga berperan penting terhadap laju pertumbuhan ekonomi (Suharyadi, dkk, 2012).

2.2 Metode analisis dalam penelitian

a) Analisis Tipologi Klassen

Analisis tipologi klassen digunakan dengan tujuan mengidentifikasi posisi sektor perekonomian Kabupaten Manggarai dengan memperhatikan sektor perekonomian Provinsi Nusa Tenggara Timur (NTT) sebagai daerah referensi. Hasil analisis Tipologi Klassen akan menunjukkan posisi pertumbuhan dan pangsa sektor, subsektor, usaha, atau komoditi pembentuk variabel regional suatu daerah.

b) Analisis Location Quotient (LQ)

Analisis LQ adalah teknik matematika yang mengukur indeks ekonomi melalui perbandingan output regional dengan output daerah referensi yang lebih luas.

c) Analisis Modal Rasio Pertumbuhan (MRP)

Model ini merupakan instrument penelitian yang digunakan untuk membandingkan pertumbuhan internal sektor di wilayah studi dan secara eksternal antara sektor yang sama dengan wilayah referensi.

d) Analisis Overlay

Analisis overlay digunakan untuk menganalisis sektor ekonomi potensial dengan pertumbuhan dan keunggulan komparatif sebagai tolak ukurnya.

e) Analisis Shift Share 
Analisis shift share merupakan analisis yang bertujuan untuk menentukan kinerja dari produktivitas perekonomian daerah dengan membandingkan dengan daerah yang lebih luas.

f) Analisis Proyeksi Shift Share

Salah satu metode proyeksi yang bisa digunakan untuk mengukur proyeksi PDRB Kabupaten Manggarai pada tahun 2016 adalah metode tren linear dalam bentuk persamaan regresi. Laju pertumbuhan PDRB pada tahun 2016 dihitung dengan bentuk persamaan.

2.3 Enam sektor dalam menunjang perekonomian nasional

1) Komponen industry mix dan pangsa daerah keduanya positif maka disebut sektor sangat kuat.

2) Komponen industry mix positif melebihi negative pangsa daerah maka disebut sektor kuat.

3) Komponen pangsa daerah positif melebihi negatif industry mix maka disebut sektor agak kuat.

4) Komponen industry mix negatif melebihi positif pangsa daerah keduanya positif maka disebut sektor agak lemah.

5) Komponen pangsa daerah negative melebihi positif industry maka disebut sektor lemah.

6) Komponen industry mix dan pangsa daerah keduanya negative maka disebut sektor sangat lemah. 


\section{BAB III \\ PENUTUP}

\subsection{Kesimpulan}

Kabupaten Manggarai telah mengalami pergeseran struktur ekonomi yang disebabkan oleh perubahan kontribusi sektor perekonomian dimana struktur ekonomi beralih dari sektor primer menuju sektor tersier. Berdasarkan analisis shift share, pergeseran struktur ekonomi terjadi karena perubahan kontribusi sector perekonomian yang signifikan dimana struktur ekonomi beralih dari sektor primer menuju sektor tersier. Pergseran tersebut disebabkan oleh adanya beberapa sektor ekonomi yang sangat kuat dalam memberikan kontribusi terhadap PDRB Kabupaten Manggarai.

\subsection{Saran}

Pemerintah daerah diharapkan mampu merumuskan kebijakan pembangunan yang tepat untuk Kabupaten Manggarai sesuai dengan kondisi perekonomian Kabupaten Manggarai yang mengalami perubahan struktur dan potensi yang dimiliki oleh beberapa sektor ekonomi unggulan agar perekonomian Kabupaten Manggarai semakin berkembang dan mengalami akselerasi pertumbuhan ekonomi yang cepat. Selainitu, diharapkan publikasi data PDRB oleh lembaga terkait dilakukan lebih cepat sehingga para pembuat kebijakan maupun para peneliti dapat lebih mudah membuat analisisnya.Walaupun sektor pertambangan dan penggalian merupakan sektor unggulan, sektor ini tidak layak untuk dikembangkan karena dampak negative berupa kerusakan lingkungan dalam aktivitas pertambangan di Kabupaten Manggarai. 


\section{DAFTAR PUSTAKA}

Ariefianto, Moch. Doddy.2012. Ekonometrika Esensi dan Aplikasi Menggunakan

EViews. Jakarta: Penerbit Erlangga.

Badan Pusat Statistik Provinsi NTT. 2016. NTT Dalam Angka. Kupang: BPS Provinsi NTT.

Badan Pusat Statistik Kabupaten Manggarai. 2016. Manggarai Dalam Angka. Kupang: BPS Kabupaten Manggarai.

Imaningsih, Niniek. 2011. Analisis Potensi Sektoral dengan Shift Share di Kabupaten

Pasuruan, Jurnal FEB UPN Veteran, hal: 12-25 . 